\title{
Effects of Water Application Rates and Planting Density on Growth Parameters of Drip Irrigated Onions ${ }^{1}$
}

\author{
Elvin Caraballo, Megh Raj Goyal and Carmela Chao de Báez ${ }^{2}$
}

\begin{abstract}
We evaluated the effects of water application rates (wet $=\mathrm{T} 1$, moist $=\mathrm{T} 2$ and $\mathrm{dry}=\mathrm{T} 3$ ) and four planting densities $(\mathrm{S} 1=$ one row at $7.5 \mathrm{~cm}$ plant spacing; $\$ 2=$ two rows at $7.5 \mathrm{~cm} ; \mathrm{S3}=$ one row at $15 \mathrm{~cm}$; and $\mathrm{S4}=$ two rows at $15 \mathrm{~cm}$ ) on growth parameters of drip irrigated onions (Allium cepa cv. Texas Grano 502) in the semi-arid southern coast of Puerto Rico. In all plots fresh bulb weight, dry bulb weight and bulb width were linearly correlated with days after transplanting. Quadratic curves described the relationships between other growth parameters (Iresh plant weight, fresh total weight, plant height, number of leaves, dry plant weight and dry total weight) with days aiter transplanting. No relationship was found between percent of total solids and days after transplanting. The coefficient of determination $\left(R^{2}\right)$ varied from 0.79 to 0.94 and the regression coefficients were significant at the $5 \%$ level.
\end{abstract}

\section{INTRODUCTION}

Goyal et al. ${ }^{3}$ found that relationships among pepper growth parameters with days after transplanting were exponential and the curves exhibited five growth phases, namely, lag phase, a log phase, a decreasing rate, a maximum growth, and a senescence phase. Goyal et al. ${ }^{4}$ indicated that the onion bulbs were heavier when plant spacing was increased from 7.5 to $15 \mathrm{~cm}$. The bulbs were significantly larger at $5 \%$ in the plots irrigated at 15 and $45 \mathrm{~cm}$ depth. More than $50 \%$ of the onions were in the size classes 6 to 12 , with less than $5 \%$ in size classes 1 to 5 and 16 to 19 , respectively. Two rows of onions on both sides of the drip line led to a significantly higher yield at the $5 \%$ level than one row on both sides of the drip line.

${ }^{1}$ Manuscript submitted to Editorial Board April 29, 1985.

This study was conducted under Southeast Regional Project S-143 (H326), "Trickle Irrigation in Humid Regions-Puerto Rico." This contributon is partly based on a MS thesis submitted by the Senior author in partial fulfillment of the requirements for the degree of Master in Science in the Faculty of Horticulture-1984. The authors thank E. Orengo and A. Morales for their suggestions.

${ }^{2}$ Research Assistant, Associate Agricultural Engineer and Associate Statistician, respectively, Agricultural Experiment Station, University of Puerto Rico, Mayagüez Campus, Rio Piedras, P.R.

${ }^{3}$ Goyal, M. R., C. L. Santiago and C. Chao de Báez, 1984. How plastic mulch types affect growth parameters of drip irrigated summer peppers. J. Agric. Univ, P.R. 68 (4): 365-73.

${ }^{4}$ Goyal, M. R., R. Guadalupe-Luna, E. Recio de Hernandez, L. E. Rivera and E. Caraballo, 1985. Effects of water application rates and planting density on size arrangements of drip irrigated onions. J. Agric. Univ. P.R. 69 (3): 383-89. 


\section{JOURNAL OF AGRICULTURE OF UNIVERSITY OF PUERTO RICO}

The objectives of this study were to evaluate the effects of water application rates (wet, moist and dry) and planting density on the growth parameters of drip irrigated onions (var. Texas Grano 502) in the semiarid region of Puerto Rico.

\section{MATERIALS AND METHODS}

This study was conducted at the Fortuna Agricultural Research and Development Center. The main treatments were three water application rates (wet $=\mathrm{T} 1$, moist $=\mathrm{T} 2$ and dry $=\mathrm{T} 3$ ) based upon tensiometers installed at 15,30 and $45 \mathrm{~cm}$ below the soil surface. The treatments were replicated six times in a randomized split-plot block design. The subtreatments were one row of onions on each side of the biwall drip line at 7.5

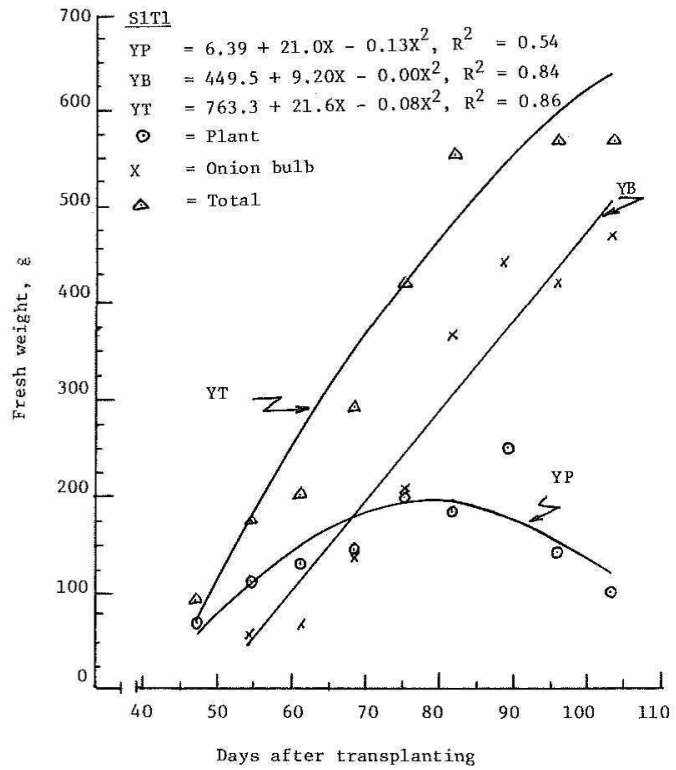

Fio. 1.-Fresh plant, bulb and total weight of drip irrigated onions. Each data point is mean of six observations. YP $=$ fresh plant weight, $\mathrm{YB}=$ fresh bulb weight, $\mathrm{YT}=$ fresh total weight. 
$\mathrm{cm}$ down the row (S1); two rows of onions on each side of the drip line at a $7.5-\mathrm{cm}$ spacing (S2); one row of onions on each side of the drip line at a 15-cm spacing (S3); and two rows of onions on each side of the drip line at a $15-\mathrm{cm}$ spacing (S4). Each plot consisted of 3 beds $90 \mathrm{~cm}$ apart and $12 \mathrm{~m}$ long. The center bed was harvested to obtain the experimental data.

Fifty-four-day-old transplants (var. Texas Grano 502) were planted December 22, 1982. Starting on the 40th day, two plants per plot were removed each successive week to evaluate plant height, number of leaves, plant fresh weight, bulb fresh weight, total fresh weight and bulb width.

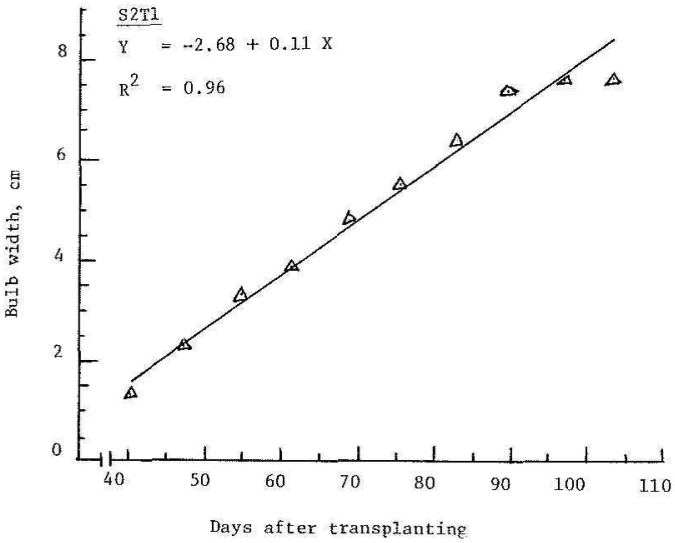

FIG. 2.-Onion bulb width. Each data point is a mean of six observations.

The samples were oven dried for 48 hours at $85^{\circ} \mathrm{C}$ to evaluate dry plant weight, dry bulb weight, dry total weight and percent total solids.

\section{RESULTS AND DISCUSSION}

Table 1 shows the relationships between the growth parameters (plant height, number of leaves, fresh plant weight, fresh bulb weight, fresh total weight, dry plant weight, dry bulb weight, dry total weight and bulb width) with days after transplanting for the wet (T1), moist (T2) and dry (T3) treatments, and for the four planting densities (S1, S2, S3 and $\mathrm{S} 4)$. The table reveals the values of the regression coefficients $(\mathrm{A}, \mathrm{B}, \mathrm{C})$ and of the coefficients of determination $\left(R^{2}\right)$. The regressions were 
TABLE 1.-Effects of water application rates and planting density on growth parameters of drip irrigated onions (Allium cepa cv. Texas Grano 502)

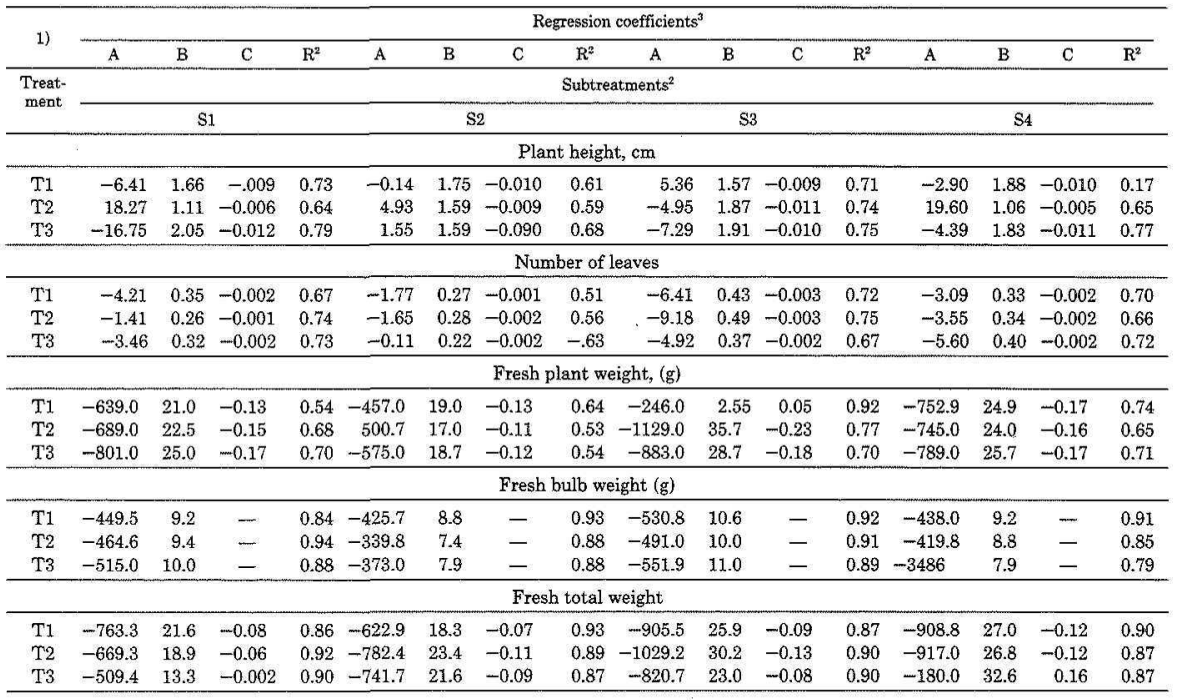


Dry plant weight $(\mathrm{g})$

\begin{tabular}{|c|c|c|c|c|c|c|c|c|c|c|c|c|c|c|c|c|}
\hline T1 & -29.0 & 1.01 & -0.006 & 0.54 & -23.2 & 0.88 & -0.006 & 0.44 & -44.8 & 1.47 & -0.009 & 0.67 & -23.1 & 0.89 & -0.006 & 0.54 \\
\hline $\mathrm{T} 2$ & -31.9 & 1.07 & -0.006 & 0.61 & -14.9 & 0.61 & -0.004 & 0.33 & -44.7 & 1.50 & -0.009 & 0.62 & -25.3 & 0.91 & -0.005 & 0.47 \\
\hline T3 & -32.9 & 1.11 & -0.007 & 0.53 & -14.7 & 0.59 & 0.004 & 0.39 & -41.4 & 1.40 & -0.008 & 0.58 & -32.6 & 1.12 & -0.007 & 0.54 \\
\hline \multicolumn{17}{|c|}{ Dry bulb weight $(g)$} \\
\hline $\mathrm{T} 1$ & -36.5 & 0.74 & - & 0.91 & -29.9 & 0.64 & - & 0.93 & -42.1 & 0.84 & - & 0.92 & -27.6 & 0.62 & - & 0.90 \\
\hline $\mathrm{T} 2$ & -36.9 & 0.75 & - & 0.94 & -25.8 & 0.57 & - & 0.81 & -35.6 & 0.75 & - & 0.87 & -32.4 & 0.69 & - & 0.86 \\
\hline $\mathrm{T} 3$ & -34.6 & 0.71 & - & 0.88 & -27.7 & 0.59 & - & 0.86 & -35.7 & 0.75 & - & 0.85 & -29.0 & 0.64 & - & 0.88 \\
\hline \multicolumn{17}{|c|}{ Dry total weight (g) } \\
\hline T1 & -32.8 & 0.85 & -0.008 & 0.91 & -39.2 & 1.14 & -0.0030 & 0.92 & -24.1 & 0.55 & -0.0030 & 0.94 & -45.5 & 1.39 & -0.005 & 00.91 \\
\hline $\mathrm{T}^{2} 2$ & -32.8 & 0.84 & -0.002 & 0.93 & -51.1 & 1.49 & -0.0060 & 0.78 & -60.9 & 1.76 & -0.0060 & 0.88 & -51.4 & 1.46 & -0.005 & 00.88 \\
\hline $\mathrm{T} 3$ & -39.8 & 1.06 & -0.002 & 00.80 & -38.7 & 1.12 & -0.0030 & 0.88 & -59.1 & 1.70 & -0.0060 & 0.87 & -60.2 & 1.78 & -0.007 & 00.88 \\
\hline \multicolumn{17}{|c|}{ Bulb width (cm) } \\
\hline $\mathrm{T} 1$ & -3.32 & 0.12 & - & 0.96 & -2.68 & 0.11 & - & 0.96 & -3.18 & 0.12 & - & 0.97 & -2.71 & 0.11 & - & 0.96 \\
\hline T2 & -2.98 & 0.11 & - & 0.96 & -2.41 & 0.10 & - & 0.94 & -3.00 & 0.11 & - & 0.96 & -2.77 & 0.11 & - & 0.94 \\
\hline $\mathrm{T} 3$ & -3.08 & 0.11 & - & 0.85 & -2.27 & 0.10 & - & 0.94 & -2.73 & 0.11 & - & 0.87 & -2.43 & 0.11 & - & 0.93 \\
\hline
\end{tabular}

${ }^{1} \mathrm{~T} 1=$ Wet; $\mathrm{T} 2=$ Moist; $\mathrm{T} 3=$ Dry.

${ }^{2} \mathrm{~S} 1=$ one line on both sides of drip line at $7.5 \mathrm{~cm}$ plant spacing; $\mathrm{S} 2=$ two lines on both sides of drip line at $7.5 \mathrm{~cm}$ plant spacing; $\mathrm{S} 3=$ one line on both sides of drip line at $15 \mathrm{~cm}$ plant spacing; $\mathrm{S} 4=$ two lines on both sides of drip line at $15 \mathrm{~cm}$ plant spacing.

${ }^{3} \mathrm{Y}=\mathrm{A}+\mathrm{BX}+\mathrm{CX} \mathrm{X}^{2}$, where $\mathrm{X}=$ growth parameter; $\mathrm{X}=$ days after transplanting; $\mathrm{A}, \mathrm{B}, \mathrm{C}=$ regression coefficients; $\mathrm{R}^{2}=$ coefficient of determination. All regression coefficients were significant at $5 \%$ level. 
significant at the $5 \%$ level. The relationships of the fresh bulb weight, the dry bulb weight and the bulb width to days after transplanting were linear (fig. 1). The relationships among other crop characteristics with days after transplanting were quadratic and of a sigmoidal type (fig. 2) exhibiting five phases of growth. ${ }^{3}$ There was no relationship between percent of total solids and days after transplanting in any of the treatments and subtreatments.

The differences among $\mathrm{S} 1, \mathrm{~S} 2, \mathrm{~S} 3$ and $\mathrm{S} 4$ were significant at the $5 \%$ level in the case of plant height on the 47th, 61st, 68th, 75th and 96th day of observation; the number of leaves on the $47 \mathrm{th}, 61 \mathrm{st}, 75 \mathrm{th}, 89 \mathrm{th}$ and 103rd day; plant fresh weight on the 61st, 68th, 75th, 82nd, 89th, 96 th and 103rd day; bulb fresh weight on the 89th and 103rd day; total fresh weight on $68 \mathrm{th}, 75 \mathrm{th}, 82 \mathrm{nd}, 96 \mathrm{th}$ and $103 \mathrm{rd}$ day; plant dry weight on the 68th, 75th, 82nd, 89 th and 96th day; bulb dry weight on the $82 \mathrm{nd}$, 96 th and 103rd day; total dry weight on the 68th, 75th, 82nd, 96th and $103 \mathrm{rd}$ day; and bulb width on the 47 th and $82 \mathrm{nd}$ day, respectively. The differences among S1, S2, S3 and S4 on other days of observation were nonsignificant at the 5\% level. The differences among T1, T2 and T3 were significant at the $5 \%$ level in the case of number of leaves on the 96 th day; bulb fresh weight on the 54th day; plant dry weight on the 75th and the 96th day; bulb dry weight on the 54th day; total dry weight on the 54th day; and bulb width on the 103rd day. The differences among $\mathrm{T} 1, \mathrm{~T} 2$ and $\mathrm{T} 3$ on other days of observation were nonsignificant at the $5 \%$ level.

This study, together with studies conducted by Goyal et al. ${ }^{4}$, shows that drip irrigation scheduling in onion should be based upon tensiometers installed at a 15 to $30 \mathrm{~cm}$ depth; onions should be planted in two rows on each side of the drip line instead of one. Spacing should be increased to $15 \mathrm{~cm}$ for heavier bulbs. Fresh bulb weight and bulb width can provide a guide for harvesting time.

\section{RESUMEN}

En la costa semiárida del sur de Puerto Rico se evaluaron los efectos de diferentes tratamientos de riego (mojado $=\mathrm{T} 1$, húmedo $=\mathrm{T} 2$ y seco $=$ T3) y cuatro densidades de siembra (S1 = una hilera de plantas a $7.5 \mathrm{~cm}$; $\mathrm{S} 2=$ dos hileras de plantas a $7.5 \mathrm{~cm}$; $\mathrm{S} 3=$ una hilera a $15 \mathrm{~cm}$; y $\mathrm{S} 4=$ dos hileras a $15 \mathrm{~cm}$ ) sobre los parámetros de crecimiento de la cebolla (Alium cepa cv Texas Grano 502) regada por goteo. En todas las parcelas el peso fresco, el peso seco y la anchura de los bulbos estuvieron correlacionados con los dias transcurridos después del trasplante. Las curvas cuadrâticas describieron la relación entre otros parámetros de 


$$
\text { VOL. 70, NO. 2, APRIL, } 1986
$$

crecimiento (peso fresco de la planta, peso fresco total, altura de la planta, número de hojas, peso seco de la planta y peso seco total) utilizando los dias después del trasplante como variables independientes. No se encontró relación significativa entre el porcentaje total de sólidos y los dias transcurridos después del trasplante. El coeficiente de determinación $\left(\mathbf{R}^{2}\right)$ varió de 0.79 a 0.94 y las regressiones fueron significativas al nivel del $5 \%$. 
